\title{
PENGARUH KEPEMIMPINAN DAN IKLIM ORGANISASI TERHADAP KINERJA PEGAWAI PT. JASAJOE PUTRA MANDIRI
}

\author{
Tri Darmawati *)
}

\section{ABSTRAK}

Penelitian bertujuan untuk mengetahui pengaruh kepemimpinan dan iklim organisasi terhadap kinerja PT. Jasajoe Putra Mandiri. Data yang digunakan pada penelitian adalah data sekunder seperti kuisioner dan dokumentasi. Metode analisis yang digunakan dalam penelitian ini yaitu metode analisis Uji Regresi Linear Sederhana, Uji Regresi Linear Berganda, Uji Korelasi (R), Uji t dan Uji f.

Hasil penelitian diperoleh hasil bahwa terdapat pengaruh Kepemimpinan terhadap Kinerja Pegawai PT. Jasajoe Putra Mandiri, hal ini dilihat dari hasil $t_{\text {hitung }}>t_{\text {tabel }}$ yaitu 3,915 $>2,012$ sehingga tolak Ho dan terima Ha. Tidak terdapat pengaruh Iklim Organisasi terhadap Kinerja Pegawai PT. Jasajoe Putra Mandiri, hal ini dilihat dari hasil $t_{\text {hitung }}<t_{\text {tabel }}$ yaitu 1,748 $<2,012$ sehingga tolak Ha dan terima Ho. Terdapat pengaruh Kepemimpinan dan Iklim Organisasi secara bersama-sama terhadap Kinerja Pegawai PT. Jasajoe Putra Mandiri, hal ini dilihat dari hasil $f_{\text {hitung }}>f_{\text {tabel }}$ yaitu 7,803 $>3,2$ sehingga tolak Ho dan terima $\mathrm{Ha}$.

Kata Kunci : Kepemimpinan, iklim organisasi, kinerja.

\section{A. Pendahuluan}

Sebuah organisasi baik kecil maupun besar dalam mencapai tujuan organisasinya tentulah tidak akan pernah terlepas dari peranan seorang pimpinan serta kinerja pegawai dalam organisasi itu sendiri. Penilaian terhadap suatu pekerjaan dalam sebuah organisasi merupakan suatu tahap evaluasi kerja yang dapat meningkatkan kualitas pekerjaan bagi kelangsungan aktivitas suatu organisasi di dalamnya. Hasil pekerjaan yang diinginkan dari para pegawai tentunya memiliki standar untuk mengukur keberhasilan kerja organisasi. Namun kualitas kerja dari beberapa pekerja tidak selamanya sesuai dengan standar yang diberlakukan. Suatu saat situasi dan kondisi tidak memungkinkan untuk mencapai tujuan dan harapan organiasi tersebut, sehingga menyebabkan penilaian terhadap kinerja yang dihasilkan menjadi menurun.

Kepemimpinan

menurut

Yaverbaum \& Sherman dalam Husaini (2010:311) Leadership is act of gaining cooperation from people in order to accomplish something. Kepemimpinan adalah tindakan mendapatkan keuntungan kerja sama dari orang untuk mencapai sesuatu. Tugas seorang pimpinan dalam menciptakan sebuah iklim organisasi yang mampu membawa para anggotanya untuk meningkatkan prestasi dalam rangka pencapaian tujuan organisasi bukanlah suatu hal yang mudah. Hal ini disebabkan karena pada dasarnya manusia memiliki karakteristik tingkah laku yang berbeda sesuai dengan tingkat kebutuhannya. Apabila terdapat perbedaan atau kesenjangan antara persepsi anggota dengan persepsi pimpinan mengenai iklim yang dirasakan dan yang diharapkan, maka hal tersebut akan memungkinkan timbulnya ketidakpuasan kerja yang tentunya berdampak pada penurunan kinerja pegawai, sehingga dapat menimbulkan penyalahgunaan hak dan kewajiban yang akhimya mengakibatkan tujuan organisasi tidak dapat tercapai atau terpenuhi secara optimal.

Persoalan-persoalan

ini semakin bertumpuk dengan kecenderungan organisasi untuk

*) Dosen Tetap Fakultas Ekonomi UPGRI Palembang 
berkembang, dan menyesuaikan diri dengan perkembangan lingkungan di sekitarnya sehingga pegawai seringkali kehilangan identitas pribadi, dan pimpinan makin sulit untuk memuaskan kebutuhan pegawai dalam mencapai tujuan organisasi sekaligus. Seorang pimpinan adalah seseorang yang mempunyai wewenang untuk memerintah orang lain. Seseorang yang dalam menjalankan pekerjaannya untuk mencapai tujuan yang telah ditetapkan, dengan menggunakan bantuan orang lain. Dengan demikian ia perlu memimpin para pegawai, tidak setiap orang yang menjadi pemimpin bisa menjalankan pekerjaannya dengan baik, tidak setiap pemimpin bisa menjadi pemimpin yang baik.

Selain faktor kepemimpinan pada organisasi, faktor lain yang diduga dapat mempengaruhi tujuan organisasi adalah iklim organisasi. Menurut Gibson et al dalam Zulkiram et al (2013:131) iklim organisasi adalah sifat lingkungan kerja atau lingkungan psikologis dalam organisasi yang dirasakan oleh para pekerja atau anggota organisasi dan dianggap dapat mempengaruhi sikap dan perilaku pekerja terhadap pekerjaannya. Dengan demikian keadaan iklim organisasi suatu organisasi akan mempengaruhi sikap dan perilaku pegawai dalam bekerja sehari-hari.

Dari observasi yang penulis lakukan di obyek penelitian teridentifikasi permasalahan sebagai berikut:

1. Diduga sebagian pegawai merasa kurang puas dengan keadaan iklim organisasi di PT. Jasajoe Putra Mandiri.

2. Diduga terdapat perbedaan atau kesenjangan antara persepsi pegawai dengan persepsi pimpinan mengenai iklim yang dirasakan dan yang diharapkan terjadi di PT. Jasajoe Putra Mandiri.

3. Diduga lambatnya penyelesaian pekerjaan karena rendahnya kepuasan pegawai atas lingkungan organisasinya pada PT. Jasajoe Putra Mandiri.

Berdasarkan fenomena di atas penulis tertarik untuk melakukan penelitian dan dapat dirumuskan permasalahan dalam penelitian ini adalah sebagai berikut:

1. Apakah terdapat pengaruh kepemimpinan terhadap kinerja pegawai PT. Jasajoe Putra Mandiri?

2. Apakah terdapat pengaruh iklim organisasi terhadap kinerja pegawai PT. Jasajoe Putra Mandiri?

3. Apakah terdapat pengaruh kepemimpinan dan iklim organisasi secara bersama-sama terhadap kinerja pegawai PT. Jasajoe Putra Mandiri?

Berdasarkan rumusan masalah yang penulis kemukakan di atas maka penelitian ini bertujuan sebagai berikut:

1) Untuk mengetahui pengaruh kepemimpinan terhadap kinerja pegawai PT. Jasajoe Putra Mandiri.

2) Untuk mengetahui pengaruh iklim organisasi terhadap kinerja pegawai PT. Jasajoe Putra Mandiri.

3) Untuk mengetahui pengaruh kepemimpinan dan iklim organisasi secara bersama-sama terhadap kinerja pegawai PT. Jasajoe Putra Mandiri.

\section{B. Kajian Teoritis}

1. Kepemimpinan

Kepemimpinan dapat diartikan sebagai kemampuan mendorong sejumlah orang (dua orang atau lebih) agar bekerjasama dalam melaksanakan kegiatan-kegiatan yang 
terarah pada tujuan bersama (Nawawi, 2000:78). Selain itu menurut Yukl (2002:34) "Leadership is the process of influencing others to understand and agree about what needs to be done and how it can be done effectivel, and the process of facilitating individual and collective efforts to accomplish the shared objective". Kepemimpinan adalah proses mempengaruhi orang lain untuk memahami dan setuju tentang apa yang perlu dikerjakan dan bagaimana tugas tersebut dapat dilakukan secara efektif, dan proses memfasilitasi usaha individu dan kelompok untuk mencapai tujuan bersama.

Sebagian besar definisi kepemimpinan mencerminkan asumsi bahwa kepemimpinan adalah proses yang disengaja oleh seseorang untuk menekankan pengaruhnya yang kuat terhadap orang lain. Ciri-ciri efektivitas kepemimpinan efektif hasil penelitian para ilmuwan lainnya, di mana para peneliti mempelajari sejumlah ciri kepribadian kepemimpinan yang berbeda dan berhubungan dengan efektivitas kepemimpinan yang dikemukakan oleh para peneliti dalam (Soekarso dan Agus, 2010:71) sebagai berikut:

1. Hadari Nawawi dan Martini

Kepemimpinan efektif adalah kepemimpinan yang mampu menggerakan anggotanya untuk mencapai tujuan kelompok atau organisasi.

2. Hasibuan.S.P Malayu

Mengemukakan bahwa seseorang pemimpin dikatakan sukses atau efektif dalam kepemimpinannya, jika:
a. berhasil merealisasikan program perusahaan dengan baik.
b. berhasil mencpai target yang telah ditetapkan.
c. berhasil meningkatkan daya guna dan hasil guna dari sumber daya.

d. berhasil mendorong semangat kerja, partisipasi dan loyalitas karyawan.

e. berhasil menjamin dan meningkatkan kontinuitas perusahaan dan semua Pilihan yang terkait memperoleh kepuasan.

f. Berhasil meningkatkan kepuasan karywan.

g. dapat membantu kebijakan perekonomian nasional.

h. Berhasil membina dan meningkatkan kedisiplinan serta kecakapan karyawan.

Ringkasannya, seorang pemimpin dikatakan sukses dan efektif dalam kepemimpinannya, jika kontinuitas perusahaan terjamin dan semua pihak yang terkait memperoleh kepuasan. Dari pendapat-pendapat ahli di atas kepemimpinan yang dimaksud adalah suatu cara yang digunakan oleh pemimpin untuk mempengaruhi orang lain dalam hal ini bawahan agar mau bekerja sehingga tujuan organisasi dapat tercapai.

Menurut pendapat yang dikemukakan Siagian (2003:66) peranan pemimpin dalam organisasi terdiri dari peranan yang bersifat interpersonal, peranan yang bersifat informasional dan peranan dalam pengambilan keputusan sebagai berikut:

1. Peranan yang bersifat interpersonal

2. Peranan yang bersifat informasional

3. Peran pengambilan keputusan, yaitu selaku entrepreneur, peredam gangguan, pembagi sumber dana dan daya, perunding bagi organisasi.

Robbins dalam Soekarso dan Agus (2010:87) mengemukakan ciriciri ideal yang harus dimiliki oleh seorang pemimpin yaitu :

1. Berpengetahuan umum yang luas.

2. Memiliki kemampuan untuk tumbuh dan berkembang. 
3. Sifat inkuistif (rasa ingin tahu).

4. Memiliki kemampuan analitik.

5. Mempunyai daya ingat yang kuat.

6. Kemampuan berkomunikasi efektif.

7. Memiliki ketrampilan mendidik.

8. Rasional dan Objektivitas.

9. Kemampuan menentukan skala prioritas.

10. Pragmatis.

11. Kemampuan membedakan yang urgen.

12. Rasa tepat waktu dan kohesi tinggi.

13. Naluri keteladanan dan relevansi.

14. Kesediaan menjadi pendengar yang baik.

15. Adaptabilitas dan Fleksibilitas.

16. Keberanian.

17. Ketegasan dan sifat antisipatif.

18. Orientasi masa depan.

\section{Iklim Organisasi}

Menurut Stinger dalam Herman et al (2014:160) Iklim Organisasi sebagai koleksi dan pola lingkungan yang menentukan munculnya motivasi serta berfokus pada persepsi-persepsi yang masuk akal atau dapat dinilai, sehingga mempunyai pengaruh langsung terhadap kinerja anggota organisasi. Iklim Organisasi merupakan kualitas lingkungan internal organisasi yang secara relatif terus berlangsung dialami oleh anggota organisasi dan mempengaruhi perilaku mereka serta dapat dilukiskan dalam satu set karakteristik atau sifat organisasi atau lembaga.

Menurut Luthans dalam Herman et al (2014:160) Iklim organisasi adalah lingkungan internal atau psikologi organisasi. Iklim organisasi mempengaruhi praktik dan kebijakan SDM yang diterima oleh anggota organisasi. Selain itu menurut Nawawi dalam Herman et al (2014:160) Iklim Organisasi adalah iklim kerja yang diciptakan dan dikembangkan secara sengaja, terjamin dan mendapat perlindungan dalam bekerja.

Menyimak beberapa pengertian atau definisi di atas ternyata belum cukup untuk mengetahui secara komprehensif tentang iklim organisasi, sehingga perlu pula dipahami masalah lingkungan organisasi, karena lingkungan organisasi baik secara langsung maupun tidak langsung akan mempengaruhi kondisi iklim organisasi.

Kita mengetahui, bahwa setiap organisasi memiliki iklim organisasi yang berbeda. Keanekaragaman pekerjaan yang dirancang di dalam organisasi, atau sifat individu yang ada tentunya akan menggambarkan perbedaan tersebut. Semua organisasi tentu memiliki strategi yang berbeda dalam memanajemen SDM. Iklim organisasi yang terbuka memacu karyawan untuk mengutarakan kepentingan dan ketidakpuasan tanpa adanya rasa takut akan tindakan balasan dan perhatian. Ketidakpuasan seperti itu dapat ditangani dengan cara yang positif dan bijaksana. Iklim keterbukaan, bagaimanapun juga hanya tercipta jika semua anggota memiliki tingkat keyakinan yang tinggi dan mempercayai keadilan tindakan.

\section{Kinerja}

Usman (2012:63), kinerja merupakan unjuk kerja seseorang dalam melaksanakan tugas-tugas yang telah dipercayakan kepadanya sesuai dengan fungsi dan kedudukannya. Rukmana (2007:3), mengatakan bahwa kinerja adalah sebagai kualitas dan kuantitas usaha yang diperoleh dari proses manajemen yang pada dasarnya kinerja tersebut merupakan hasil kerja periode tertentu melalui cara membandingkan dengan target yang telah disepakati bersama. Menurut Herman et al (2014:161) Kinerja adalah tentang 
melakukan pekerjaan dan hasil yang dicapai dari pekerjaan tersebut. Kinerja adalah tentang apa yang dikerjakan dan bagaimana cara mengerjakan. Kinerja merupakan hasil pekerjaan yang mempunyai hubungan kuat dengan tujuan strategis organisasi, kepuasan konsumen dan memberikan kontribusi ekonomi.

Gomes (2005:135) menyatakan kinerja adalah catatan yang dihasilkan dari fungsi suatu pekerjaan tertentu atau kegiatan selama periode waktu tertentu. Sedangkan Veithzal (2004:309) mengatakan bahwa kinerja merupakan perilaku nyata yang ditampilkan setiap orang sebagai prestasi kerja yang dihasilkan oleh karyawan sesuai dengan perannya dalam perusahaan. Pendapat yang sama disampaikan oleh As'ad (2003:35) bahwa kinerja berhubungan dengan sikap dari karyawan terhadap pekerjaannya, situasi kerja, kerjasama antara pemimpin dengan karyawan, dan antar sesama karyawan.

Dengan demikian dapat disimpulkan kinerja merupakan unjuk kerja seseorang dari proses manajemen tentang apa yang dikerjakan dan hasil yang dicapai dari pekerjaan sesuai dengan perannya dalam perusahaan.

Berdasarkan kajian teori di atas, maka penulis mengajukan hipotesis sebagai berikut:

1. Diduga terdapat pengaruh kepemimpinan terhadap kinerja pegawai pada PT. Jasajoe Putra Mandiri.

2. Diduga terdapat pengaruh iklim organisasi terhadap kinerja pegawai pada PT. Jasajoe Putra Mandiri.

3. Diduga terdapat pengaruh kepemimpinan dan iklim organisasi secara bersama-sama terhadap kinerja pegawai pada PT. Jasajoe Putra Mandiri.

\section{Metode Penelitian}

Variabel dalam penelitian ini berjumlah tiga variabel, yang terdiri dari dua variabel bebas dan satu variabel terikat. Variabel bebas untuk penelitian ini adalah variabel Kepemimpinan $\left(\mathrm{X}_{1}\right)$ dan variabel Iklim Organisasi $\left(X_{2}\right)$, variabel terikatnya yaitu variabel Kinerja Pegawai $(Y)$.

Masing-masing variabel tersebut didefenisikan sebagai berikut:

1. Kepemimpinan $\left(X_{1}\right)$ adalah proses mempengaruhi orang lain untuk memahami dan setuju tentang apa yang perlu dikerjakan dan bagaimana tugas tersebut dapat dilakukan secara efektif, dan proses memfasilitasi usaha individu dan kelompok untuk mencapai tujuan bersama.

2. Iklim Organisasi $\left(X_{2}\right)$ adalah sebagai koleksi dan pola lingkungan yang menentukan munculnya motivasi serta berfokus pada persepsipersepsi yang masuk akal atau dapat dinilai, sehingga mempunyai pengaruh langsung terhadap kinerja anggota organisasi.

3. Kinerja (Y) adalah unjuk kerja seseorang dari proses manajemen tentang apa yang dikerjakan dan hasil yang dicapai dari pekerjaan sesuai dengan perannya dalam perusahaan.

Menurut Sugiyono (2005:25), populasi adalah wilayah generaliasi yang terdiri dari objek dan subjek yang mempunyai kualitas dan karakteristik tertentu yang diterapkan oleh peneliti untuk dipelajari dan kemudian ditarik kesimpulan. Populasi dan sampel dalam penelitian ini adalah keseluruhan pegawai yang ada di PT. Jasajoe Putra Mandiri yang berjumlah 49 orang.

Teknik pengumpulan data yang dilakukan dalam penelitian ini adalah melalui wawancara, kuisioner, observasi dan dokumentasi. Kuisioner 
dengan menggunakan skala sikap, dan diuji dengan uji validitas dan realibilitas. Setelah instrumen kuisioner valid dan reliabel kemudian disebar dan data-data yang terkumpul akan diuji asumsi dengan cara uji normalitas, uji homogenitas dan uji linearitas.

Analisis pada data penelitian digunakan statistik deskriptif dan statistik inferensial. Statistik deskritif dipilih dan dipergunakan dengan maksud untuk menggambarkan karakteristik penyebaran skor setiap variabel dengan menghitung rata-rata, median, simpangan baku, skor tertinggi, skor terendah.

Statistik inferensial dalam penelitian ini digunakan mencari analisis sebagai berikut:

1. Regresi linear sederhana, yaitu untuk mencari kaitan antara variabel bebas dan variabel terikat secara parsial dengan persamaan sebagai berikut:

$\hat{Y}=a+b 1 X 1+e$

2. Regresi linear berganda, yaitu untuk mencari kaitan antara variabel bebas secara bersamasama dengan variabel terikat dengan persamaan sebagai berikut:

$\mathrm{Y}=\mathrm{a}+\mathrm{b} 1 \mathrm{X} 1+\mathrm{b} 2 \mathrm{X} 2+\mathrm{e}$

3. Analisis Korelasi Parsial, yaitu untuk melihat hubungan variabel bebas dengan variabel terikat.

4. Analisis Korelasi Berganda, yaitu untuk melihat hubungan kedua variabel bebas secara bersamasama dengan variabel terikat.

Untuk memberikan penafsiran terhadap koefisien korelasi, maka dapat digunakan tabel sebagai berikut:
Tabel 1

Interpretasi terhadap Koefisien Korelasi

\begin{tabular}{|c|c|}
\hline Interval Koefisien & $\begin{array}{c}\text { Tingkat } \\
\text { Hubungan }\end{array}$ \\
\hline $0,00-0,199$ & Sangat rendah \\
\hline $0,20-0,399$ & Rendah \\
\hline $0,40-0,599$ & Sedang \\
\hline $0,60-0,799$ & Kuat \\
\hline $0,80-1,000$ & Sangat Kuat \\
\hline
\end{tabular}

Sumber : Sugiyono (2004:184)

5. Uji Hipotesis, yaitu pengujian yang dilakukan untuk mengetahui ada atau tidaknya pengaruh variabel bebas terhadap variabel terikat. Uji hipotesis yang digunakan dalam penelitian ini adalah sebagai berikut:

a. Uji t, yaitu uji hipotesis dengan langkah-langkah sebagai berikut:

1) Pengaruh Kepemimpinan (X1) terhadap Kinerja Pegawai (Y)

Menentukan hipotesis $\mathrm{X} 1$ terhadap $Y$

Ho : Tidak terdapat pengaruh Kepemimpinan

Terhadap Kinerja

Pegawai PT. Jasajoe Putra Mandiri.

$\mathrm{Ha}$ : Ada pengaruh signifikan

Kepemimpinan

Terhadap Kinerja

Pegawai PT. Jasajoe Putra Mandiri.

Kriteria Pengujian

Ho diterima $\mathrm{Ha}$ ditolak jika $t_{\text {hitung }}<t_{\text {tabel }}$, artinya bahwa tidak terdapat pengaruh Kepemimpinan terhadap Kinerja Pegawai PT. Jasajoe Putra Mandiri.

Ho ditolak $\mathrm{Ha}$ diterima jika $t_{\text {hitung }}>t_{\text {tabel }}$, artinya bahwa terdapat pengaruh Kepemimpinan terhadap 
Kinerja Pegawai PT. Jasajoe Putra Mandiri.

2) Pengaruh Iklim Organisasi (X2) terhadap Kinerja Pegawai $(Y)$

Menentukan hipotesis $\mathrm{X} 2$ terhadap $Y$

Ho: Tidak terdapat pengaruh Iklim Organisasi terhadap Kinerja Pegawai PT. Jasajoe Putra Mandiri.

$\mathrm{Ha}$ : Terdapat pengaruh Iklim Organisasi terhadap Kinerja Pegawai PT. Jasajoe Putra Mandiri.

Kriteria Pengujian

Ho diterima $\mathrm{Ha}$ ditolak jika $t_{\text {hitung }}<t_{\text {tabel }}$, artinya bahwa tidak terdapat pengaruh Iklim Organisasi terhadap Kinerja Pegawai PT. Jasajoe Putra Mandiri

Ho ditolak $\mathrm{Ha}$ diterima jika $t_{\text {hitung }}>t_{\text {tabel }}$, artinya bahwa Terdapat pengaruh Iklim Organisasi terhadap Kinerja Pegawai PT. Jasajoe Putra Mandiri

b. Uji f, yaitu pengujian yang dilakukan untuk mengetahui pengaruh variabel bebas (X1 dan $\mathrm{x} 2$ ) secara bersama-sama terhadap variabel terikat $(\mathrm{Y})$. Uji $f$ dilakukan dengan langkah-langkah sebagai berikut:

1) Menentukan hipotesis $X 1$ dan X2 terhadap $Y$

Ho: Tidak terdapat pengaruh

Kepemimpinan dan Iklim Organisasi secara bersama-sama terhadap Kinerja Pegawai PT. Jasajoe Putra Mandiri.
Ha: Terdapat pengaruh Kepemimpinan dan Iklim Organisasi secara bersama-sama terhadap Kinerja Pegawai PT. Jasajoe Putra Mandiri.

2) Kriteria Pengujian Ho diterima Ha ditolak jika $t_{\text {hitung }}<t_{\text {tabel }}$, artinya bahwa tidak terdapat pengaruh Kepemimpinan (X1) dan Iklim Organisasi (X2) secara bersama-sama terhadap Kinerja Pegawai PT. Jasajoe Putra Mandiri.

Ho ditolak $\mathrm{Ha}$ diterima jika $t_{\text {hitung }}>t_{\text {tabel }}$, artinya bahwa Terdapat pengaruh Kepemimpinan (X1) dan Iklim Organisasi (X2) secara bersama-sama terhadap Kinerja Pegawai PT. Jasajoe Putra Mandiri

\section{Hasil dan Pembahasan Penelitian}

Untuk uji coba instrumen menggunakan uji validitas, uji reliabilitas dan untuk uji asumsi digunakan uji normalitas, homogenitas dan lineritas. Hasilnya instrumen variabel Kepemimpinan, Iklim Organisasi dan Kinerja dinyatakan valid, reliabel, data berdistribusi normal, homogen dan linear antara variabel bebas dan terikat.

Dari hasil pengolahan data diperoleh analisis statistik deskriptif terhadap Variabel kepemimpinan dengan hasil skor data rentangan (range) antara 35-54, skor minimum sebesar 35 dan skor maksimum 54, dengan range sama dengan 19 , skor rata-rata sebesar 42, median 41, modus 38 , simpangan baku 5,084 dan varians sebesar 25,844 . Variabel iklim organisasi dengan hasil skor data rentangan (range) antara 32-48, skor 
minimum sebesar 32 dan skor maksimum 48, dengan range sama dengan 16, skor rata-rata sebesar 36,92 median 36, modus 37, simpangan baku 3,796 dan varians sebesar 14,410. Variabel kinerja pegawai dengan hasil skor data rentangan (range) antara 34-54, skor minimum sebesar 34 dan skor maksimum 54, dengan range sama dengan 20, skor rata-rata sebesar 43,31 median 42, modus 42, simpangan baku 4,891 dan varians sebesar 23,925.

\section{Uji Regresi Linier Sederhana}

Hasil pengolahan data menggunakan program SPSS diperoleh hasil sebagai berikut:

Tabel 2

Analisis Regresi Sederhana Kepemimpinan (X1) terhadap Kinerja (Y)

\begin{tabular}{|c|c|c|c|c|c|}
\hline \multirow[b]{2}{*}{ VARIABEL } & \multicolumn{2}{|c|}{$\begin{array}{l}\text { Unstandardized } \\
\text { Coefficients }\end{array}$} & $\begin{array}{c}\text { Standardized } \\
\text { Coefficients }\end{array}$ & \multirow[b]{2}{*}{$\mathrm{T}$} & \multirow[b]{2}{*}{ Sig. } \\
\hline & B & Std. Error & Beta & & \\
\hline (Constant) & 3.555 & 10.171 & & .350 & .728 \\
\hline KEPEMIMPINAN & .986 & .252 & .496 & 3.915 & .000 \\
\hline
\end{tabular}

Sumber : Hasil Pengolahan Data dengan SPSS

Berdasarkan hasil pengolahan
data pada tabel 2 dapat diintepretasikan sebagai berikut:

- Diperoleh persamaan regresi linear sederhana $\hat{Y}=3,555+0,986 X_{1}+$ e

- Melalui persamaan tersebut diketahui pengaruh Kepemimpinan terhadap Kinerja bernilai positif. Konstansta sebesar 3,555 artinya jika Kepemimpinan (X1) nilainya adalah 0 , maka Kinerja $(Y)$ nilainya sebesar 3,555. Nilai b sebesar 0,986 mengandung arti bahwa bila terjadi kenaikan pada Kepemimpinan sebesar 1 satuan, maka akan terjadi peningkatan Kinerja sebesar 0,986 satuan.

Tabel 3

Analisis Regresi Sederhana Iklim Organisasi (X2) terhadap Kinerja (Y)

\begin{tabular}{|c|c|c|c|c|c|}
\hline \multirow[b]{2}{*}{ Model } & \multicolumn{2}{|c|}{$\begin{array}{l}\text { Unstandardized } \\
\text { Coefficients }\end{array}$} & \multirow{2}{*}{$\begin{array}{c}\begin{array}{c}\text { Standardized } \\
\text { Coefficients }\end{array} \\
\text { Beta }\end{array}$} & \multirow[b]{2}{*}{$\mathrm{T}$} & \multirow[b]{2}{*}{ Sig. } \\
\hline & B & Std. Error & & & \\
\hline (Constant) & 31.552 & 6.758 & & 4.668 & .000 \\
\hline IKLIMORG & .318 & .182 & .247 & 1.748 & .087 \\
\hline
\end{tabular}

Sumber : Hasil Pengolahan Data dengan SPSS

Berdasarkan hasil pengolahan data pada tabel 3 dapat diintepretasikan sebagai berikut:

- Diperoleh persamaan regresi linear sederhana $\hat{Y}=31,552+0,318 X_{1}+$ e
- Melalui persamaan tersebut diketahui pengaruh Iklim Organisasi terhadap Kinerja bernilai positif. Konstansta sebesar 31,552 artinya jika Iklim Organisasi (X2) nilainya adalah 0 , maka Kinerja (Y) nilainya sebesar 31,552. 
Nilai b sebesar 0,318 mengandung arti bahwa bila terjadi kenaikan pada Iklim Organisasi sebesar 1 satuan, maka akan terjadi peningkatan Kinerja sebesar 0,318 satuan.
Uji Regresi Linier Berganda

Hasil pengolahan data menggunakan program SPSS diperoleh hasil sebagai berikut:

\section{Tabel 4}

Analisis Regresi Berganda Kepemimpinan (X1) dan Iklim Organisasi (X2) secara bersama-sama terhadap Kinerja (Y)

\begin{tabular}{|c|c|c|c|c|c|}
\hline \multirow[b]{2}{*}{ Model } & \multicolumn{2}{|c|}{$\begin{array}{c}\text { Unstandardized } \\
\text { Coefficients }\end{array}$} & \multirow{2}{*}{$\begin{array}{c}\text { Standardized } \\
\text { Coefficients }\end{array}$} & \multirow[b]{2}{*}{$\mathrm{T}$} & \multirow[b]{2}{*}{ Sig. } \\
\hline & B & Std. Error & & & \\
\hline (Constant) & 1.669 & 10.607 & & .157 & .876 \\
\hline IKLIMORG & .117 & .174 & .091 & .674 & .504 \\
\hline KEPEMIMPINAN & .926 & .269 & .465 & 3.442 & .001 \\
\hline
\end{tabular}

Sumber : Hasil Pengolahan Data dengan SPSS

Berdasarkan hasil pengolahan
data pada tabel 4 dapat diintepretasikan sebagai berikut:

- Diperoleh persamaan regresi linear berganda

$$
\hat{Y}=1,669+0,926 X_{1}+0,117 X_{2}+e
$$

- Melalui persamaan tersebut diketahui pengaruh Kepemimpinan dan Iklim Organisasi terhadap Kinerja bernilai positif. Konstansta sebesar 1,669 artinya jika Kepemimpinan (X1) dan Iklim Organisasi (X2) nilainya adalah 0 , maka Kinerja (Y) nilainya sebesar 1,669. Nilai b1 sebesar 0,926 mengandung arti bahwa bila terjadi kenaikan pada Kepemimpinan sebesar 1 satuan dengan asumsi Iklim Organisasi nilainya adalah 0 , maka akan terjadi peningkatan Kinerja sebesar 0,926 satuan. Nilai b2 sebesar 0,117 mengandung arti bahwa bila terjadi kenaikan pada Iklim Organisasi sebesar 1 satuan dengan asumsi Kepemimpinan nilainya adalah 0 , maka akan terjadi peningkatan Kinerja sebesar 0,117 satuan.

\section{Uji Korelasi Linier Sederhana}

Hasil pengolahan data menggunakan program SPSS diperoleh hasil sebagai berikut:

Tabel 5

Analisis Korelasi Sederhana Kepemimpinan (X1) terhadap Kinerja (Y)

\begin{tabular}{|l|c|r|r|r|}
\hline Model & $\mathrm{R}$ & $\mathrm{R}$ Square & $\begin{array}{c}\text { Adjusted R } \\
\text { Square }\end{array}$ & $\begin{array}{c}\text { Std. Error of } \\
\text { the Estimate }\end{array}$ \\
\hline 1 & $.496^{\mathrm{a}}$ & .246 & .230 & 4.292 \\
\hline
\end{tabular}

Sumber : Hasil Pengolahan Data dengan SPSS

Berdasarkan hasil pengolahan data pada tabel 5 dapat diintepretasikan bahwa korelasi (R) antara Kepemimpinan (X1) dengan Kinerja
(Y) sebesar 0,496. Hal ini berarti hubungan Kepemimpinan (X1) dengan Kinerja ( $\mathrm{Y}$ ) adalah sedang. 
Tabel 6

Analisis Korelasi Sederhana Iklim Organisasi (X2) terhadap Kinerja (Y)

\begin{tabular}{|l|c|r|r|r|}
\hline Model & $\mathrm{R}$ & $\mathrm{R}$ Square & $\begin{array}{c}\text { Adjusted R } \\
\text { Square }\end{array}$ & $\begin{array}{c}\text { Std. Error of } \\
\text { the Estimate }\end{array}$ \\
\hline 1 & $.247^{\mathrm{a}}$ & .061 & .041 & 4.790 \\
\hline
\end{tabular}

Sumber : Hasil Pengolahan Data dengan SPSS

Berdasarkan hasil pengolahan data pada tabel 6 dapat diintepretasikan bahwa korelasi $(\mathrm{R})$ antara Iklim Organisasi (X2) dengan Kinerja (Y) sebesar 0,247. Hal ini berarti hubungan Iklim Organisasi (X2) dengan Kinerja (Y) adalah rendah.

Tabel 7

Analisis Korelasi Berganda Kepemimpinan (X1) dan Iklim Organisasi (X2) secara bersama-sama terhadap Kinerja (Y)

\begin{tabular}{|l|r|r|r|r|}
\hline Model & R & R Square & $\begin{array}{c}\text { Adjusted R } \\
\text { Square }\end{array}$ & $\begin{array}{c}\text { Std. Error of } \\
\text { the Estimate }\end{array}$ \\
\hline 1 & $.503^{\text {a }}$ & .253 & .221 & 4.318 \\
\hline \multicolumn{2}{|l}{ Sumber : Hasil Pengolahan Data dengan SPSS } \\
\hline
\end{tabular}

\section{Uji Korelasi Linier Berganda}

Hasil pengolahan data menggunakan program SPSS diperoleh hasil sebagai berikut:
Berdasarkan hasil pengolahan data pada tabel 7 dapat diintepretasikan bahwa korelasi $(\mathrm{R})$ antara Kepemimpinan (X1) dan Iklim Organisasi (X2) secara bersama-sama dengan Kinerja $(Y)$ sebesar 0,503. Hal ini berarti hubungan Kepemimpinan (X1) dan Iklim Organisasi (X2) secara bersama-sama dengan Kinerja $(\mathrm{Y})$ adalah sedang.

Uji Hipotesis menggunakan Uji t

Pengujian untuk mengetahui ada tidaknya pengaruh dari masing-masing variabel bebas terhadap variabel terikat secara parsial dilakukan dengan uji t, sebagai berikut:

Tabel 8

Uji t Kepemimpinan (X1) terhadap Kinerja (Y)

\begin{tabular}{|c|c|c|c|c|c|}
\hline \multirow[b]{2}{*}{ VARIABEL } & \multicolumn{2}{|c|}{$\begin{array}{l}\text { Unstandardized } \\
\text { Coefficients }\end{array}$} & $\begin{array}{c}\text { Standardized } \\
\text { Coefficients }\end{array}$ & \multirow[b]{2}{*}{$\mathrm{T}$} & \multirow[b]{2}{*}{ Sig. } \\
\hline & B & Std. Error & Beta & & \\
\hline (Constant) & 3.555 & 10.171 & & .350 & .728 \\
\hline KEPEMIMPINAN & .986 & .252 & .496 & 3.915 & .000 \\
\hline
\end{tabular}

Berdasarkan hasil pengolahan data pada tabel 8 diketahui $t_{\text {hitung }}$ sebesar 3,915. Tabel distribusi t dicari pada alpha $=5 \%$ dengan derajat kebebasan (DF) n-k-1 atau 49-1-1=47. Hasil diperoleh untuk tabel $0,05 / 2$ sebesar 2,012. Dengan demikian thitung $>t_{\text {tabel }}$ yaitu 3,915 > 2,012 sehingga tolak Ho dan terima Ha yaitu terdapat pengaruh Kepemimpinan terhadap Kinerja Pegawai PT Jasajoe Putra Mandiri. 
Tabel 9

Uji t Iklim Organisasi (X2) terhadap Kinerja (Y)

\begin{tabular}{|c|c|c|c|c|c|c|}
\hline \multirow{2}{*}{\multicolumn{2}{|c|}{ Model }} & \multicolumn{2}{|c|}{$\begin{array}{l}\text { Unstandardized } \\
\text { Coefficients }\end{array}$} & \multirow{2}{*}{$\begin{array}{c}\text { Standardized } \\
\text { Coefficients }\end{array}$} & \multirow[b]{2}{*}{$\mathrm{T}$} & \multirow[b]{2}{*}{ Sig. } \\
\hline & & B & Std. Error & & & \\
\hline & (Constant) & 31.552 & 6.758 & & 4.668 & .000 \\
\hline & IKLIMORG & .318 & .182 & .247 & 1.748 & .087 \\
\hline
\end{tabular}

Sumber : Hasil Pengolahan Data dengan SPSS

Berdasarkan hasil pengolahan data pada tabel 9 diketahui thitung sebesar 1,748 . Tabel distribusi t dicari pada alpha $=5 \%$ dengan derajat kebebasan (DF) n-k-1 atau 49-1-1=47. Hasil diperoleh untuk tabel 0,05/2 sebesar 2,012. Dengan demikian thitung $<t_{\text {tabel }}$ yaitu $1,748<2,012$ sehingga tolak $\mathrm{Ha}$ dan terima Ho yaitu tidak terdapat pengaruh Iklim Organisasi terhadap Kinerja Pegawai PT Jasajoe Putra Mandiri.

\section{Uji Hipotesis menggunakan Uji f}

Pengujian untuk mengetahui ada tidaknya pengaruh dari variabel bebas secara bersama-sama terhadap variabel terikat dilakukan dengan uji $f$, sebagai berikut:

Tabel 10

Uji f Kepemimpinan (X1) dan Iklim Organisasi (X2) secara bersama-sama terhadap Kinerja $(Y)$

\begin{tabular}{|l|c|c|c|c|c|}
\hline Model & $\begin{array}{c}\text { Sum of } \\
\text { Squares }\end{array}$ & DF & $\begin{array}{c}\text { Mean } \\
\text { Square }\end{array}$ & $\mathrm{F}$ & Sig. \\
\hline $\begin{array}{l}\text { Regression } \\
\text { Residual }\end{array}$ & 290.923 & 2 & 145.461 & 7.803 & $.001^{\mathrm{a}}$ \\
$\quad$ Total & 857.485 & 46 & 18.641 & & \\
\hline
\end{tabular}

Sumber : Hasil Pengolahan Data dengan SPSS

Berdasarkan hasil pengolahan data pada tabel 10 diketahui $f_{\text {hitung }}$ sebesar 7,803 . Tabel distribusi f dicari pada alpha $=5 \%$ dengan derajat kebebasan (DF) n-k-1 atau 49-2-1=46. Hasil diperoleh untuk $t_{\text {tabel }} \quad 0,05 / 2$ sebesar 3,20. Dengan demikian $\mathrm{f}_{\text {hitung }}>$ $f_{\text {tabel }}$ yaitu $7,803>3,2$ sehingga tolak Ho dan terima $\mathrm{Ha}$ yaitu terdapat pengaruh Kepemimpinan dan Iklim Organisasi secara bersama-sama terhadap Kinerja Pegawai PT. Jasajoe Putra Mandiri.

\section{E. Kesimpulan dan Saran \\ Berdasarkan hasil penelitian dan pembahasan, maka penulis menarik kesimpulan sebagai berikut :}

1. Terdapat pengaruh Kepemimpinan terhadap Kinerja Pegawai PT Jasajoe Putra Mandiri, hal ini dilihat dari hasil $t_{\text {hitung }}>t_{\text {tabel }}$ yaitu 3,915 $>$ 2,012 sehingga tolak Ho dan terima $\mathrm{Ha}$.

2. Tidak terdapat pengaruh Iklim Organisasi terhadap Kinerja Pegawai PT Jasajoe Putra Mandiri, hal ini dilihat dari hasil $t_{\text {hitung }}<t_{\text {tabel }}$ yaitu $1,748<2,012$ sehingga tolak Ha dan terima Ho.

3. Terdapat pengaruh Kepemimpinan dan Iklim Organisasi secara bersama-sama terhadap Kinerja Pegawai PT. Jasajoe Putra Mandiri, hal ini dilihat dari hasil 
$f_{\text {hitung }}>f_{\text {tabel }}$ yaitu $7,803<3,2$ sehingga tolak $\mathrm{Ho}$ dan terima $\mathrm{Ha}$.

Berdasarkan kesimpulan di atas, maka dapat disampaikan saran yaitu:

1. Organisasi harus memilih pemimpin yang tepat sehingga dengan kepemimpinan yang lebih baik diharapkan akan meningkatkan kinerja pegawai.

2. Walaupun Iklim organisasi tidak mempengaruhi kinerja pegawai secara signifikan, namun pimpinan organisasi tetap harus memperhatikan keadaan iklim organisasi mengingat hubungannya positif dengan kinerja pegawai.

3. Perlu dilakukan penelitian lanjutan untuk mencari faktor-faktor lain yang dapat meningkatkan kinerja pegawai.

DAFTAR PUSTAKA

As'ad, Muhammad. 2003. Kinerja sebagai Media Peningkatan Derajad dalam Konteks Industrialisasi. Bandung, Geneca.

Gomes, Faustino Cardoso. 2005. Manajemen Sumber Daya Manusia. Yogyakarta, Andi.

Herman. Djailani dan Sakdiah. 2014. "Pengaruh Iklim Organisasi dan Kepuasan Kerja terhadap Kinerja Guru" Jurnal Administrasi Pendidikan Pascasarjana Universitas Syiah Kuala. Vol. 4, No.2: 157-167.

Husaini, Usman. 2010. Manajemen Riset dan pendidikan, Jakarta, Bumi Aksara.

Nawawi, Hadari dan Martini Hadari, 2000. Kepemimpinan yang Efektif, Yogyakarta, Gajah Mada University press.

Rukmana, N. 2007. Kepemimpinan yang berlandaskan Adversitas
Kecerdasan Emosional dan Kecerdasan Spiritual. Bandung, SDM, Artikel.

Siagian, Sondang P, 2003, Pengembangan Sumber Daya Insan. Jakarta, Gunung Agung.

Soekarso. Agus Sosro, 2010. Teori Kepemimpinan. Jakarta, Mitra wacana.

Sugiyono. 2004. Metode Penelitian Bisnis. Cetakan ke-6, Bandung, CV. Alfabeta.

Usman, Nasir. 2012. Manajemen Peningkatan Mutu Kinerja Guru (Konsep, Teori dan Model), Bandung, Cita Pustaka Media Perintis.

Veithzal, Rivai. 2004. Manajemen Sumber Daya Manusia untuk Perusahaan: dari Teori ke Praktek. Jakarta, PT. Raja Grafindo Persada.

Yukl, Gary. 2002. Leadership in Organization. 5th Edition, USA, Prentice Hall International.

Zulkiram. Mukhlis dan Amri. 2013. "Pengaruh Iklim Organisasi, Disiplin Kerja dan Kompensasi terhadap Kinerja Pegawai serta dampaknya pada Kinerja Lembaga Pemasyarakatan Klas IIA Banda Aceh" Jurnal Manajemen Pascasarjana Universitas Syiah Kuala. Vol. 2, No.1: 128-137. 